\title{
Újraéledő francia iparpolitika - új dilemmák, kihívások és eszközök
}

\section{Industrial policy revival in France: new dilemmas, challenges and instruments}

\author{
EGYED ILDIKÓ, PÓLA PÉTER
}

EGYED Ildikó: tudományos munkatárs, Közgazdaság- és Regionális Tudományi Kutatóközpont, Regionális Kutatások Intézete; 7621 Pécs, Papnövelde u. 22.; egyed@rkk.hu; https://orcid.org/0000-0002-8711-6270

PÓLA Péter: tudományos munkatárs, Közgazdaság- és Regionális Tudományi Kutatóközpont, Regionális Kutatások Intézete; 7621 Pécs, Papnövelde u. 22.; pola@rkk.hu; https://orcid.org/0000-0003-3169-2874

KULCSSZAVAK: újraiparosodás; iparpolitika; innováció; Mittelstand; középvállalatok; startup vállalkozások; Franciaország

ABSZTRAKT: Franciaországban - ahol gyakran a német Mittelstand vállalatokat tekintik nemcsak példának, de versenytársnak is - a nagyvállalati fejlesztési modell megrekedése után ismételten napirenden az újraiparosítás. Ezúttal a figyelem fókuszában a középvállalatok, azoknak is egy speciális köre, az ETI-k, valamint a startup cégek kerültek. A dezindusztrializáció negatív hatásai, amit a 2008-as válság tovább súlyosbított, sok vitát generáltak részben a beavatkozás szükségességével, részben annak mikéntjével kapcsolatban. A decentralizált Németországhoz való felzárkózás, az ipari versenyképesség bázisát jelentő Mittelstand-modell sikeresebb alkalmazása komoly kihívás a centralizáltabb berendezkedésű Franciaországban. Az elemzések kimutatták, hogy az ipar relatív elmaradásának hátterében leginkább a gyengébb innovációs teljesítmény jelenik meg. Ezért az állami intézmények és támogatási rendszerek erőteljesen fókuszálnak az innovációs teljesítmény javítására. Bár a vita nem dőlt el, egyre inkább az iparpolitika szükségessége mellett érvelők kerülnek többségbe, úgy tűnik, ismét egy ipart támogató állami politika van kibontakozóban. Annak kapcsán, hogy ez hogyan, milyen eszközökkel történjen, még nagyon nem látszik konszenzus. A francia iparpolitika jelenleg oszcillál a közép- és nagyvállalatokat középpontba állító, valamint a kiemelten a startup vállalkozásokat támogató, ezeket különféle kormányzati eszközökkel támogatni szándékozó nézetek és gyakorlatok között. A két elképzelésben az innováció intenzív támogatása a közös vonás. Egyelőre annak a jelei kevésbé, vagy csak nagyon áttételesen rajzolódnak ki, hogy milyen módon segíti a francia gazdaság- és fejlesztéspolitika és intézményrendszere annak az üzleti környezetnek, infrastruktúrának a fejlesztését, amely ezt az innovációalapú iparpolitikát hatékonyan képes támogatni, illetve hogyan müködik a lokális, regionális üzleti infrastruktúra, az oktatási és szakképzési rendszer, amely az innovációt és az ipari teljesítményt közvetetten, de annál eredményesebben tudja ösztönözni.

Ildikó EGYED: research fellow, Institute for Regional Studies, Centre for Economic and Regional Studies; Papnövelde u. 22., H-7621 Pécs, Hungary; egyed@rkk.hu; https://orcid.org/0000-0002-8711-6270 Péter PÓLA: research fellow, Institute for Regional Studies, Centre for Economic and Regional Studies; Papnövelde u. 22., H-7621 Pécs, Hungary; pola@rkk.hu; https://orcid.org/0000-0003-3169-2874

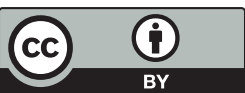


KEYWORDS: industrial policy; innovation; Mittelstand; intermediate-sized firms

ABSTRACT: France, which tends to regard the German Mittelstand companies not merely as 'role models' but competitors, has recently embraced reindustrialization after abandoning its previous colbertist development model. The main foci of the 'new industrial policy' are intermediate-sized companies (ETI) and start-up firms. The negative impacts of deindustrialisation, exacerbated by the 2008 crisis, have generated much controversy about the necessity and methods of state intervention. Catching up with the decentralized German state by implanting the highly competitive Mittelstand model poses a significant challenge for France owing to its strong tradition of centralization.

Analyses have demonstrated a strong interrelationship between relative industrial underdevelopment and the weakness of innovative performance. Therefore, the main target of state institutions and funding mechanisms is to ameliorate industrial innovative performance. Albeit some controversy remains, there is growing support in favor of a more active industrial policy and state-subsidized industrial innovation. Currently, there is a plethora of economic and industrial policy-related instruments and institutions whose role is to ameliorate the business environment which risks a fragmentation of resources. French industrial policy is currently oscillating between financing medium-sized and large companies and supporting the dynamic growth of start-ups through targeted interventions. Both approaches share an overriding concern for innovation.

It is still difficult to measure the efficiency of economic and development policy interventions targeting the modernization of the business environment and infrastructure underpinning France's innovation-led industrial policy. It is of utmost importance to understand the operation of local, regional business infrastructure, education and vocational training systems that might enhance innovation and industrial performance in indirect yet highly efficient ways.

\section{Bevezetés}

Tanulmányunk „A hazai középvállalati szektor szerepe az ipar területi versenyképességében" c. OTKA-kutatás keretei között készült. Ennek során azt próbáltuk feltárni, hogy a hazai tulajdonú középvállalkozások milyen szerepet játszanak a helyi iparfejlődésben; milyen lehetőségek és kihívások jellemzik működésüket, hogyan működnek együtt az őket körülvevő gazdasági és társadalmi környezettel. A magyarországi kutatások mellett vizsgáltuk a középvállalatok fejlődésének nemzetközi példáit, mindenekelőtt a középvállalati szektorban több tekintetben is példaértékű német „Mittelstand” fejlődését, amelyek gazdasági-társadalmi vonatkozásaik és térbeli jellemzőik miatt is figyelmet érdemelnek. Jelen tanulmány a francia iparpolitika változásait és jelenlegi dilemmáit ismerteti. Vizsgáljuk részben a dezindusztrializáció számos negatív hatását, s az ebből következő reakciókat, a születő válaszokat, amelyek nem meglepően egy sajátos reindusztrializáció kibontakozását mutatják. Először egy új vállalati kategória, a regionális középvállalatok kerültek fókuszba, majd egyre inkább a startupizáció jelei erősödtek fel. Vizsgáljuk a dezindusztrializáció hatásait, a reindusztrializáció folyamatában a Mittelstand-modellt adaptálni kívánó kísérleteket, az innovációalapú fejlesztések hátterét. Bemutatjuk a kapcsolódó állami eszközöket, s foglalkozunk az ipari vállalkozások fejlődését támogató regionális, lokális intézményekkel, az üzleti környezettel. 
A francia iparfejlesztésben egy sajátos vállalati méretkategóriát alkottak és helyeztek fókuszba: ezek a „köztes méretü” vállalkozások az ETI-k (Entreprise de Taille Intermédiaire) a klasszikus KKV-k és az óriásvállalatok között helyezkednek el, s részben tőlük várják a francia ipar újraélesztését. A másik fontos fókuszt a startup vállalkozások jelentik. Egyelőre nem látszik, hogy melyik mellett kötelezi el magát a francia politika, tartós lehet-e a két kategória együttes fókusza. Kihívásokat leginkább három ponton érzékelhetünk. Az első rögtön egy kettős kihívás: miként lehet a sikeres startup cégek fejlődését támogatva részben a versenyképes középvállalatok körébe emelni őket, részben segíteni a két szektor közötti együttmüködéseket. További kihívást jelent, hogy mindkét vállalati körnél valósuljanak meg jelentős innovációs teljesítmények. Végül lényeges, hogy az általános gazdaságfejlesztési politika olyan üzleti és infrastrukturális hátteret teremtsen, amely segíti a célok megvalósulását. Ebben a regionális intézményrendszernek is kitüntetett szerepe van.

\section{A francia dezindusztrializáció következményei és a válságból való kiútkeresés}

A 250 fö feletti vállalatok egyharmadát, az export 55\%-át, a magánszektorbeli foglalkoztatottak, a teljes hozzáadott érték, az adózás előtti üzleti forgalom, valamint a beruházások 25-25\%-át koncentráló ipari ágazat 1980 és 2007 között évente átlagosan 71 ezer munkahelyet veszített. Az ipari munkahelyek látványos csökkenését az ipari tevékenységek 25\%-át érintő kiszervezés, a javuló termelékenység, valamint a védelmet élvező ágazatokra nehezedő versenynyomás (Demmou 2010) indokolta. Az ipari ágazat hanyatlásáról szóló elemzések (CNI 2011; Cohen, Buigues 2014; Gallois 2012; Fontagné, Mohnen, Wolff 2014; Groupe BPCE 2016; Cercle de l'Industrie 2017) egyöntetűen megállapítják, hogy az 1980-1990-es évek óta az alacsony költségű, feltörekvő országok gazdasági nyitása következtében felgyorsuló dezindusztrializáció a francia ipart súlyos, ám korántsem fátumként kezelendő válságba sodorta. A 2010-es évek elejéig a fogalom létjogosultságát is viták övezték (Roustan 2004; Nesta 2011), egyes kormányzati jelentések még mítoszként vetették el a dezindusztrializáció tényét (Bost, Messaudi 2017). A probléma valódi súlyosságának felismerésében kulcsszerepet játszott a legnagyobb dezindusztrializációs veszteségeket felhalmozó francia autóipari ágazat. ${ }^{1}$ A dezindusztrializáció a 2010-es évekre ért el olyan kritikus szintet, amely már az ipari bázis „destrukturálásával” fenyegetett (Cohen, Buigues 2014). A Gallois-jelentés szerint a francia gazdaság romló versenyképessége a felelős a dezindusztrializáció és a külkereskedelmi hiány súlyosbodásáért (Gallois, Lubin, Thiard 2012). Az ipari kapacitások leépülése, az importtermékek arányának növekedése miatt a külkereskedelmi mérleg hiánya 2000 óta nagyjából 50 milliárd euró körül mozog (2018-ban elérte az 59,9 Md eurót). A romló tendenciát a fel- 
dolgozóipari ágazatoknál alacsonyabb termelékenységű szolgáltatás-külkereskedelmi többlet sem képes ellensúlyozni.

A franciaországi dezindusztrializáció sajátos intenzitása és szerteágazó következményei - az ipari hozzáadott érték, munkahelyek, vállalatok arányának látványos csökkenése, ${ }^{2}$ a francia vállalatok európai pozícióinak megrendülése, a beruházási dinamika visszaesése, a külkereskedelmi mérleg tartós hiánya, stb. - miatt az ipari leépülés megállitásának illetve „visszafordíthatóságának” lehetősége a mai napig intenzív viták tárgyát képezi. A dezindusztrializáció megítélése nem egyöntetü: az aktív technológiai és iparpolitikát szorgalmazó vállalatvezetők és ipari érdekvédelmi csoportok ${ }^{3}$ a nemzetgazdasági teljesítmény és az ipari ágazat mindenkori pozíciója közötti szoros összefüggés mellett érvelnek. Ahhoz azonban, hogy a trend megforduljon, az alacsony hatásfokú és hosszú távú szemléletet nélkülöző iparpolitikák helyett paradigmaváltásra, a francia gazdaság újraiparosítását megalapozó iparfejlesztési stratégiára van szükség (Beffa 2005, Blanc 2004). Az újraiparosítás irányában szkeptikus nézőpontot képviselők szerint az ipar térvesztése visszafordíthatatlan folyamat, egyúttal a gazdasági fejlettség fokmérője is (Landier 2013). A fejlett nyugati székhelygazdaságokra jellemző módon a francia gazdaság is magas fokon tercierizálódott, az ipar és a szolgáltatások közti választóvonalak egyre elmosódottabbá válnak (Veltz 2013) a „hiperipar” fogalmával írja le a jelenséget), ennek látható jeleként ma már az ipari vállalati alkalmazottak több mint fele szolgáltatásokra specializálódik (Ceci-Renaud 2016), továbbá növekszik a gyárak nélküli üzleti modellek népszerűsége is.

A dezindusztrializáció negatív hatásait a 2008-as pénzügyi válság tovább fokozta, annak egyik fö vesztese éppen a francia ipar. A stagnáló növekedés 2009 és 2015 közötti időszakában a nagyvállalati munkahelyek tízezrei szűntek meg, miközben a francia középvállalatok 335 ezer új munkahelyet teremtettek, a KKV-k pedig ennek csak töredékét (96 400). A középvállalatok a 2009 és 2017 közötti teljes időszakot tekintve is a munkahelyteremtés fó motorjai voltak. A középvállalati szektor kiemelkedő rugalmasságának köszönhetően a válságból való kilábalás szimbólumává vált. Az iparpolitikai recept szerint a regionális gazdaságok motorját jelentő vállalati kör megerősödése megoldást nyújthat a stagnáló növekedés, a leépítések, a külkereskedelmi hiány problémájára, valamint az ipari ágazat romló nemzetgazdasági pozíciójának helyreállítására. A szektor gyenge növekedési üteme (1 200 új tag 2008 és 2018 között) azonban nem teszi lehetővé a francia ipar környező országokkal szembeni versenyhátrányának leküzdését. Míg Franciaországban csupán 5 800, Németországban 12 500, az Egyesült Királyságban 10 500, Olaszországban pedig 8000 tagot számlál a középvállalati szektor (Institut Montaigne 2018). Croirier, a francia KV-okat tömörítő egyesület (METI) elnöke úgy fogalmaz, hogy ha Franciaországban annyi közepes méretű vállalkozás lenne, mint Németországban, azzal a munkanélküliség szinte megszüntethető lenne, s hozzáteszi: Franciaország újraiparosítása elképzelhetetlen nélkülük. 


\section{A középvállalatok az iparpolitika fókuszában: a francia Mittelstand felé?}

A válságot követő években megszaporodtak a francia vállalati szektor gyenge versenyképességét a német gazdaság gerincét jelentő tőkeerős és exportorientált középvállalati bázis (Mittelstand) hiányának tulajdonító tanulmányok és elemzések (Bourgeois 2010; Gallois, Lubin, Thiard 2012; Fabre 2013; Stoffaës 2008). A diagnózis szerint a nagyszámú, kisméretű cégek által dominált KKV-szektor és a kevésszámú óriásvállalat közötti hiányzó láncszem - az erős regionális középvállalati bázis - kiszélesítése érdekében indokolt az őket célzottan segítő szabályozási környezet kialakítása. A modellként szolgáló Mittelstand vállalat egyaránt utalhat a statisztikai értelemben vett német KKV-k, az adott réspiacon világvezető pozíciójú, kiemelkedően innovatív, ám a nyilvánosság körében kevésbé ismert „rejtett bajnokok” (Gattaz 2010; Guinchard 2014), illetve a francia közepes méretủ vállalat (ETI) új keletủ fogalmára, amely a középvállalatok hiányának diagnosztizálását követően, a 2008-as Gazdasági Modernizációs Törvény nyomán került be a statisztikai nyilvántartásba. A definíció értelmében középvállalat (a továbbiakban: KV) minden olyan 250-5 000 fös vállalat, amely 50 millió euró és 1,5 milliárd euró közötti üzleti forgalmat realizál, mérlegföösszege pedig nem haladja meg a 2 milliárd eurót (1. ábra). A KV méretkategóriája alapján az európai nomenklatúrában a nagyvállalatéhoz közelít inkább, de fontos megjegyezni, hogy

1. ábra: Vállalkozások kategóriái Franciaországban

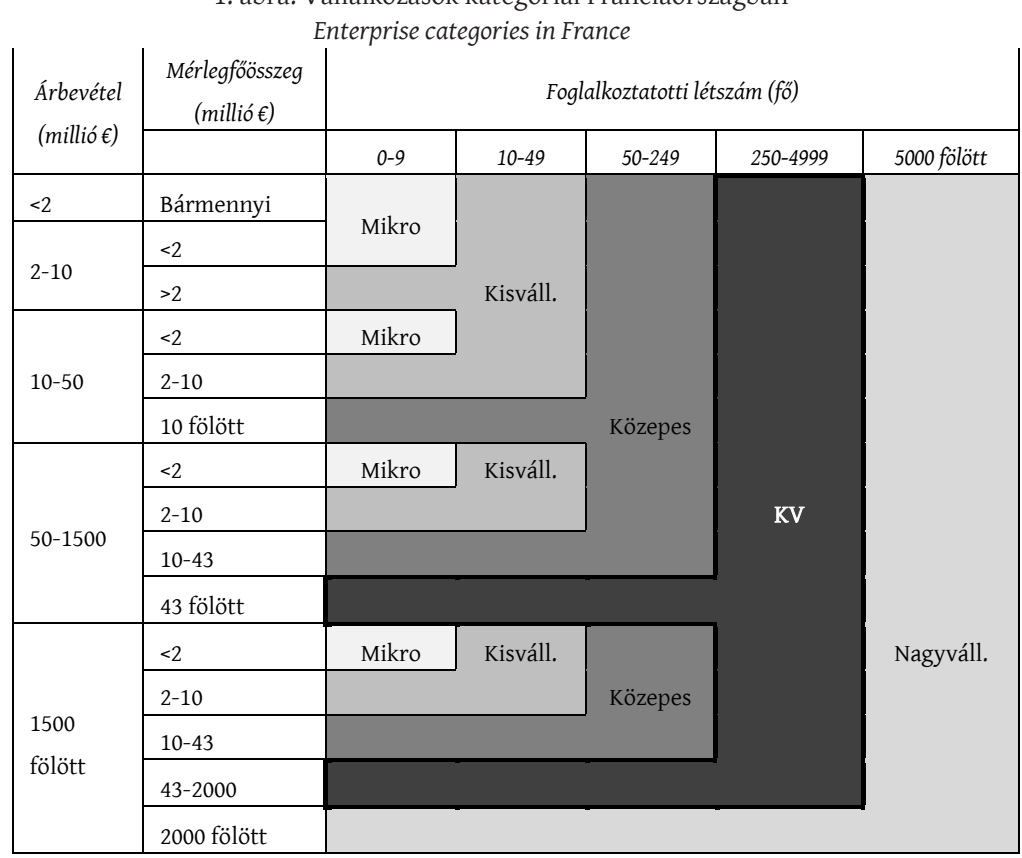

Forrás: Cnis, Rapport du groupe de travail sur la définition des catégories d'entreprises, 13. 
jelentős részük a létszámadatok alapján kisebb méretű, 2/3-uk 500 főnél kevesebb foglalkoztatottal rendelkezik, s csupán 15\%-uk foglalkoztat 1000 fonnél többet (DGCIS 2010).

A francia középvállalati szektoron belül 40\%-os súlyt képviselő mintegy 5400 feldolgozóipari jellegü KV termeli meg a francia GDP 39\%-át, az összes export és a feldolgozóipari munkahelyek egyharmada is hozzájuk köthetö, s 2009 és 2016 között 130 ezer munkahelyet teremtettek (Haehnsen 2017). Nem véletlen, hogy 2008 után a „hiányzó láncszemként” feltüntetett KV-ok kerültek a francia ipar revitalizációjáról szóló stratégiák homlokterébe (Chabaud, Messeghem 2014; Retailleau 2009; Stoffaës 2008), a reindusztrializáció hívei a fejlődés motorjaként tekintenek ezekre a vállalatokra.

A középvállalatokra irányuló kiemelt közpolitikai figyelem számos okból is indokolt:

- kulcsszerepük van az ország gazdasági versenyképességének javításában;

- az ipar-és technológiai politika középvállalat-központú;

- fontos területfejlesztő funkció (mintegy 74\%-uk île-de-France régión kívül);

- a NV és KKV-szektorénál magasabb beruházási ráta (beruházások/üzleti forgalom);

- (méretükből eredően) magasabb ellenállóképesség, hitelfelvételi képesség, hozzáadott érték, piacnövelési lehetőségek, mindamellett a KKV-knál alacsonyabb rugalmasság, piaci alkalmazkodóképesség;

- nyílt, kooperatív innováció jellemző rájuk, együttműködnek az induló vállalkozásokkal, startup cégekkel, kutatóközpontokkal, egyetemekkel, a versenyképességi klaszterekkel (pólusokkal);

- jelentős szerepet vállalhatnak a startupok technológiai fejlesztésében, termékeik gyártásában, akár a nemzetközi piacokon való megjelenésüket is támogathatják. Ez a fajta ökoszisztéma már létezik, de további erősítése nagyon fontos eleme a francia ipar megerősödésének.

A decentralizált, területileg kiegyenlítettebb Németországhoz való felzárkózás, az ipari versenyképesség bázisát jelentő Mittelstand-modell imitációja komoly kihívást jelent a gyengébben teljesítő és mindmáig erőteljes centralizációs jegyeket mutató Franciaország számára. ${ }^{4}$ Az eltérő kulturális sajátosságok mellett tudatos gazdaságpolitikai döntések is hozzájárultak a 90-es évek elejéig még hasonló teljesítményt nyújtó francia és német gazdaság közti fejlettségbeli szakadék kialakulásában. A II. világháborút követő német iparfejlődési pálya sajátosságait tükröző Mittelstand-modell feltételei - a dezindusztrializáció elmaradása, az ipari nagyvállalatok felszámolása, a harmadik utas szociális piacgazdasági modell bevezetése, a központi kormányzati stratégiaalkotás/decentralizált végrehajtás kettőssége, a bottom-up építkezésű ipari ökoszisztémák, a szabadpiaci feltételek között működő, térségileg beágyazott középvállalati szektor jelenléte - Franciaországban nem voltak adottak. A gazdaság társadalmi beágyazottsága - a polgárosodott, az individuumot a középpontba állító pluralista társadalom lapos 
hierarchiák mentén történő szerveződését is beleértve - a német vállalkozói kultúrában is érvényesül (Bleuel 2018; DGCIS 2010). A Mittelstand elsősorban történelmi-kulturális jelenség és nem statisztikai lehatárolási probléma: a jellemzően a volt NSZK területén működő, a német vállalati szektor 99\%-át lefedő, 500 főnél kisebb Mittelstand vállalatokat olyan kvalitatív tényezők miatt méltatja a szakirodalom, mint a rövidtávú gazdasági érdekek helyett a társadalmi felelősségvállalás, a családi tulajdon dominanciája, a tulajdon és a vezetés egysége, illetve a fejlett duális képzési rendszer működtetése és finanszírozása.

A francia középvállalati szektor fejlődését a történelmi-kulturális tényezők (késői iparosodás, családi vállalkozás eszméjével ellentétes republikánus filozófiák) mellett a II. világháború utáni colbertista gyökerü gazdaságpolitika (Colletis 2012), az állami kutatások-állami vállalatok-állami megrendelések háromszögére alapuló dirigizmus (De Gaulle, Pompidou), a 80-as évek szigorú megszorító politikái, majd a 90-es évek mindenfajta iparpolitikát mellőző keynesiánus gazdaságpolitikai fordulata is hátráltatta. A francia gazdaság versenyelőnyeit top-down logika mentén megalapozó, a 80-as évek közepéig uralkodó nagyvállalat centrikus iparpolitika, valamint a nehézkesen haladó decentralizációs reformok következtében Franciaországban eltérően alakult az állam, az ipar és a térségek viszonya, mint Németországban. Az offenzív protekcionizmust (Cohen 2007) alkalmazó, „nagy nemzeti bajnokok" létrehozását célzó állami iparpolitika látványos sikereket ért el az indikatív tervezés apoteózisát jelentő 1970-es években az infrastruktúra (TGV), a telekommunikáció, a repülőgépipar, a nukleáris ipar területén. A korábbi állami-vegyes tulajdonú vállalatok (Alstom, France Télécom, Airbus, Safran, Total) ma már a francia tőzsdén jegyzett globális nagyvállalatok. Más ágazatokban, ahol a protekcionista, állami megrendelésekre alapuló modell nem tudott érvényesülni, a colbertizmus totális kudarcot vallott. A kormányzati kudarcot jól példázza az informatikai ágazat terén nemzeti és technológiai szuverenitást megcélzó Plan Calcul terv, a veszteséges Concorde projekt, vagy a Crédit Lyonnaise. 1984 és 2004 között az iparpolitika megszűnt, illetve alárendelődött a horizontális logikájú európai verseny- és innovációs politikáknak. Noha a veszteséget termelő vállalatoknak (,canards boiteux"), a csúcsipari nagyprojekteknek osztott támogatási források elapadtak, a túl nagy a csődhöz elve érvényben maradt számos multinacionális vállalat (France Telecom, Air France, Credit Lyonnais, Renault, Alstom) állami megmentésében (Levy 2008).

A „francia Mittelstand-szektor” létrehozására irányuló iparpolitika sikerét a dezindusztrializáció, valamint a gazdasági fejlettséggel párhuzamba állitott tercierizáció elörehaladottsága is megkérdőjelezheti. A francia ipar GDP-hez való hozzájárulása a '90-es évek óta 17\%-ról 11\%-ra csökkent, Németországban 23\%-os hozzájárulásával továbbra is megőrizte húzóágazat szerepét (Cercle de l'Industrie 2017). Németországban a dezindusztrializáció elmaradása, az ország újraegyesítésével keletkező zöldmezős beruházási lehetőségek, valamint a berlini fal leomlását követően az olcsó munkaerőt kínáló közép- és kelet-európai térség vállalatainak be- 
szállítói láncokba történő integrációja kedvezően befolyásolta a német vállalati szektor fejlődését. A '89 utáni időszak Franciaországban a keynesiánus keresletoldali politikáknak és a gyárak nélküli (kis eszközigényü) iparért zajló kampánynak kedvezett. A nem stratégiai jelentőségü gyártási tevékenységeket érintő delokalizációs hullámoknak köszönhetően a francia ipar erősségei (nukleáris ágazat, autóipar, élelmiszeripar, gyógyszeripar) hanyatlásnak indultak, csupán a repülőgépipar és a kevésbé K+F-igényes luxusipar őrizte meg vezető pozícióját. A dezindusztrializáció következtében az Európai Unió országai közül Franciaországban a legalacsonyabb az iparvállalatok összvállalati szektorra vetített részaránya (Cailletaud 2018; Tavernier 2019). A delokalizáció „,bajnokai”, a legnagyobb leépítéseket végrehajtó francia autógyártók 2000 és 2016 között 10\%-ról 50\%-ra növelték az alacsony költségű országokba kitelepített üzemekben hazai piacra gyártott személygépkocsik arányát (Dahmani, Gazaniel, Rioust 2015). A két legnagyobb gyártó - a PSA és a Renault - 2004 és 2013 között 100 ezer munkahelyet szüntetett meg, a franciaországi gyárakban összeszerelt gépjárművek arányát pedig 30, illetve 20\%-ra csökkentették (CCFA 2019; Tavernier 2019). Az alacsony hozzáadott értékü tevékenységek delokalizációját nem követte a K+F-egységek kihelyezése, így állhat elő az a sajátos helyzet, hogy az ipari hozzáadott értékben csekély súlyt (4,3 és 3,4 Mrd $€$ ) képviselo autóipari és repüléstechnikai ágazatok vezetik a listát a vállalati $\mathrm{K}+\mathrm{F}$ ráfordítások terén (MESRI-SIES 2020).

A franciánál nyitottabb és exportfüggőbb német gazdasági modellből következik a Mittelstand-szektor - exportképesség, nemzetköziesedés, innovativitás terén - megmutatkozó abszolút fölénye (Bleuel 2018; Hénard 2012). A 2010-es évek elején a német exportáló vállalatok (98\%-ban Mittelstandok) száma elérte a 350 ezret, míg Franciaországban csak 105 ezret regisztráltak. A fö exportőrök nem az arányukat tekintve a franciáknál kisebb csoportot képviselő globális nagyvállalatok. A német gazdaság gerincét jelentő Mittelstand vállalatok állítják elő a vállalati export 70\%-át, míg a francia KV-k esetében ez az arány csupán $36 \%$ (Guinchard 2014). Franciaországban 2018-ban a 270 nagyvállalat adta az export 53\%-át, az exportáló vállalatok 4\%-át jelentő KV-ok annak egyharmadát, míg a 95\%-ukat jelentő KKV-k annak csupán 13\%-át (2. ábra). A francia KKV-k külpiaci aktivitása gyengébb, mint a főbb európai versenytársaiké és ritkán képesek exportképes középvállalattá fejlődni (Business France 2018). A tíz vagy afeletti foglalkoztatottal rendelkező francia vállalatokon belül a nagy növekedési potenciállal rendelkező vállalatok aránya az EU átlaga alatt van (Bignon, Simon 2018). Az európai mércével is kimagasló vállalkozásindítási dinamika (2019-ben 750 ezer új vállalkozás) magas mortalitási rátával párosul: az új vállalkozások több mint fele csődbe megy, mielőtt elérné az ötéves kort. Az európai KKV-k nemzetköziesedését vizsgáló felmérés eredményei szerint míg az EU tagországok többségében a KKV-k adják a belső piacra irányuló export cca. 50\%-át, Franciaország esetében ez az arány csupán $21 \%$. A francia KKV-k gyenge külpiaci aktivitásában a nemköltségalapú versenyképesség tényezőinek (innováció, szolgáltatások, minőség) 
2. ábra: Az exportálló vállalatok jellemzői, 2018

Profile of exporting enterprises, 2018
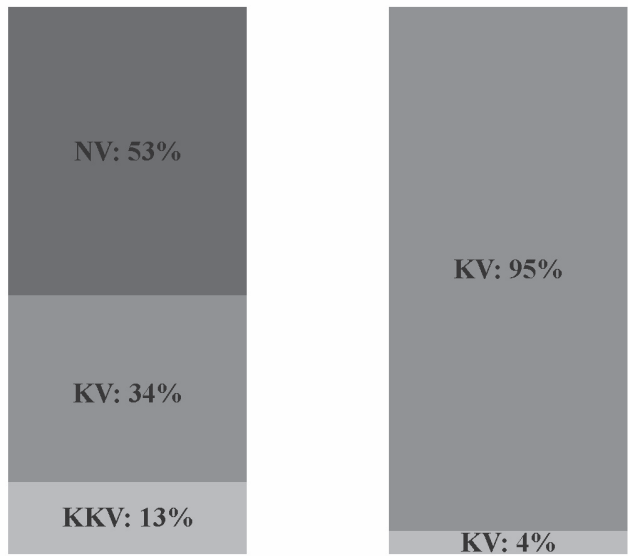

Forrás: Giraud 2019, 21.

fejletlensége, a külföldi piacszerzés iránti ambíció hiánya, a támogatási forrásokhoz való hozzáférés nehézségei is szerepet játszanak (Les PME dans l'Union européenne... 2017).

A német középvállalati szektorhoz való felzárkózást nagymértékben megnehezíti a francia cégek alacsony fokú digitalizációja, a KV-szektoron belül a kisméretű (500 főnél kisebb) cégek dominanciája (amelyek könnyen visszafejlődhetnek KKV-vá), a külföldi tulajdonú (többnyire felvásárolt) KV-ok jelentős súlya (28\%), a rejtett bajnokok ${ }^{5}$ csekély száma, valamint a cégutódlások csökkenő aránya. A lapos és decentralizált struktúrában múködő német vállalatokkal szemben a francia vállalati szerveződést uraló vertikális hierarchiák és azok konfliktusossága is negatívan befolyásolja a vállalati termelékenységet, innovációs képességet és növekedést. A francia vállalatok számára a folyamatos termékfejlesztésnél hangsúlyosabb prioritást jelent a diszruptív innováció, míg a Mittelstand vállalatok fó erőssége az inkrementális innováció, amely egyben a „made in Germany” márkával azonosított kiemelkedő termékminőség és a szektor hosszú távú stabilitásának legfőbb biztosítéka is (Industrial Strategy Fund 2012). A német vállalatok világpiaci versenyelőnye a közepes és magas technológiai színvonalú termékek gyártásán alapszik, a francia vállalatok a közepes és alacsony technológiai intenzitású árucikkek gyártásárára való szakosodás következtében könnyen versenyhátrányba kerülhetnek a feltörekvő országok hasonló piaci szegmensben versenyző vállalataival szemben. A 90-es évek közepétől a 2010-es évek elejéig a vállalati $\mathrm{K}+\mathrm{F}$ ráfordítások összege Franciaországban 14\%-kal csökkent, míg Németországban $20 \%$-kal nőtt. A francia vállalati szektor gyenge $\mathrm{K}+\mathrm{F}+\mathrm{I}$ teljesítménye az alacsony technológiai színvonalú iparágak túlsúlyával magyarázható.

A francia vállalatvezetők megítélése szerint a francia gazdaság legfőbb versenyhátránya az európai országokénál kedvezőtlenebb fiskális környezet. A 
Világbank Doing Business versenyképességi rangsorában (amely tíz kritérium alapján vizsgálja, hogy az adott országban milyen könnyű vállalkozást indítani és folytatni) Franciaország a 32. helyen, közvetlenül Oroszország mögött található (World Bank 2018). A francia üzleti környezetet leginkább terhelő tényezők a hitelhez jutás feltételei (99. hely), valamint a tulajdonátruházás (96. hely). A KV-ok számának növelése előtt álló egyik legfontosabb akadály a tőke adóztatásának javitásával elmozdítható lenne. A KV-ok túlnyomó többsége generációs vállalkozás, egy-egy ilyen cég jelenlegi állapota, sikeressége jellemzően két-három generáció eredménye. A generációs jellegből adódik, hogy fokozottan kell támogatni, segíteni a generációváltást, hogy ennek sikere megalapozhassa a hosszú távú fejlődést, ami a KV-ok lényegi eleme. E két elem (adópolitikai környezet, generációs jelleg) összefügg: egy ilyen „generációs növekedési projektet” jelentősen visszavethet, ha az adószabályozási környezet a részvények értékesítését, a vagyon szétaprózódását segíti. Ezért a vagyonadózás és az örökösödési illeték újraszabályozására van szükség. A vagyonadóra kifizetett pénzek a berendezések korszerűsítésétől és az innovációtól vonják el a forrásokat. A METI a kedvezőbb német adójogszabályokkal magyarázza egyebek mellett azt, hogy míg Németországban a cégek 65\%-ában, Olaszországban a cégek 70\%-ában sikeres a generációváltás, addig ez Franciaországban csupán 12\%. A francia tulajdonú termelő vállalatok, a know-how megőrzése, a vállalati szektor dinamizmusa szempontjából kiemelten fontos lenne a generációváltás elősegítése. A francia KKV-k és KV-ok 83\%-a ugyanis családi vállalkozás, a vállalatvezetők $50 \%$-a pedig 65 év feletti. A vállalati életciklus kezdeti fázisait túlhangsúlyozó közpolitikai intézkedések mellett ez idáig csekély szándék mutatkozott a sikeres cégátruházások arányának javítását célzó intézkedések meghozatalára. A gazdaságilletve iparpolitika egyik legfontosabb célkitűzése, hogy az átruházás fiskális feltételeinek javítása révén, a cégeken belüli sikeres generációváltás a jelenlegi 12\%-os szintről 50\%-ra emelkedjen.

A francia vállalatok versenyképességének fejlesztése a munkaerö és az adózás költségeinek csökkentésénél kezdődik. Az EU-ban a munkaerő költségeinek szintje Franciaországban az egyik legmagasabb. A KV-oknál nagyon jól fizetett innovációs, robotizációs és marketingszakemberekre van szükség. Az adózási környezet a termelési oldalon is komoly probléma: a termelési adók mértéke - a Németországra jellemző hétszerese - európai mércével is kiugróan magas (a francia GDP 2\%-a, a vállalatok által létrehozott HÉ 3,6\%-a). Az Európai Unión belül csak Svédországban magasabb a termelési adók állami adóbevételeken belüli súlya (41\% szemben a francia 25\%-kal), míg Németországban a legalacsonyabb (5\%). A termelési adók összege ráadásul 2010 óta tendenciaszerüen a GDP-növekedést meghaladó ütemben növekszik. Az INSEE számításai szerint a KV-ok esetében a bruttó eredmény 42\%-a, a nagyvállalatok, valamint a KKV-k esetében annak 37, illetve 30\%-a kerül levonásra termelési adók formájában (Dubief et al. 2018; Institut Montaigne 2019). 


\section{Nemzeti innovációs politika - középpontban a vállalati innovációs teljesítmény}

A kiemelkedően innovatív francia gazdaság legfőbb gyengesége az innovatív vállalatok alacsony aránya, a vállalati szféra elégtelen K+F aktivitása. 2014 és 2016 között a francia vállalatok kevesebb mint 50\%-a végzett innovációs tevékenységet. A német KKV-k szabadalmi aktivitása négyszeresen meghaladja a francia KKV-két. A szabadalmak 57\%-a nagyvállalati szektortól származik. A fó szabadalmaztatók a globális innovátorok, a francia tőzsdén jegyzett, primer gazdaságot alkotó MNC-k (EDF, Total, Alstom, l'Oréal, Airbus, Vicat, Michelin, Sanofli stb.) és sikeres startupok, velük szemben helyezkednek el a növekedésre és nemzetköziesedésre képtelen KKV-k. Az ország néhány csúcsinnovátor nagyvállalat és jelentős szabadalmi aktivitást mutató állami kutatószerv (CEA, CNRS, IFP Energies Nouvelles) jelenlétének köszönheti a nemzetközi innovációs rangsorokban elfoglalt kiemelkedő pozícióját. ${ }^{6}$ A 2019-es Innovációs Eredménytábla az EU-átlag felett teljesítő Franciaországot az erős innovátorok csoportjába sorolja.

A nemzeti innovációs politika a 2000-es évektől, különösen a Lisszaboni stratégiával vált jelentős tényezővé - 2000 és 2014 között az innovációra szánt támogatások összege 3,5 milliárdról 8,7 milliárd euróra emelkedett (Pisany-Ferry 2016). A K+F erőfeszítések terén (49,5 Mrd €, a GDP 2,22\%-a) azonban még nem sikerült teljesíteni a kitűzött 3\%-os célt. A K+F kiadások (GERD) csupán 56\%-a ered a magánszférából. Az EU országai közül Franciaországban a legjelentősebb a vállalatok K+F-ráfordításait ösztönző állami támogatások súlya a GDP mintegy 0,4\%-a (INSEE 2019). Az innováció finanszírozási rendszerében az állami támogatások csökkenő trendje $(19,1 \%)$ mellett az intervencionista politikák szempontjából leginkább semleges fiskális ösztönzők (CIR, JEI)7 dominálnak (60\%). A francia vállalatok gyengén teljesítenek a partnerségen alapuló innovációs együttműködések terén, amint azt az állami kutatószervekhez, egyetemekhez kiszervezett, a vállalati szektor által finanszírozott szerződéses kutatások alacsony aránya (5,2 \%) is jelzi.

A 2004-től az „új iparpolitika” alcímet viselő innovációs politika fókuszába a többszereplős innovációs projektek kerültek. Blanc „Növekedési Ökoszisztéma" (2004) címü jelentése a klasztert állította középpontba, mint a gazdag országok számára a 21. századi innovációs gazdaságnak megfelelő új gazdasági modell alapját, ezáltal is véglegesen szakítva a francia colbertista tradícióba ágyazott „grands projets” politikájával. Az európai gyakorlatnak megfelelő és a piaci kudarcok elméletén nyugvó klaszterpolitika a francia gazdaság redinamizálása érdekében a hagyományos területfejlesztési politika logikájával ellentétes módon a legdinamikusabb térségekre és ipari erősségekre koncentrálja az erőforrásokat. A Blanc-jelentés által megalapozott és a globális versenyképesség mellett a területi kiegyenlítődési politikának is alárendelt versenyképességi pólus program fókuszába a területi innovációs rendszerek, a tudományos és technológiai kiválósági ágazatok, a régiók ,ipari erősségeire” és a területi szereplők közti partnerkapcso- 
latokra épülő diszruptív innovációs projektek kerültek. A tervezők szemében a kritikus tömeget elérő, diszruptív innovációkat létrehozó, nemzetközi láthatóságra és világszínvonalra törekvő pólusok a vállalati fúziók, a KKV-k növekedésének, középvállalattá válásának ideális kereteit jelentették. Emellett a top-down módon koncepcionált pólusprogram regionalizációja is szerepelt a célok között: noha a 2005 és 2018 közti időszakban a 4000 innovációs projekt tekintélyes részét (46\%) a magánszféra (4,5 Mrd $€$ ) és a FUI- ${ }^{8}$ keresztül az állam (1,8 Mrd $€$ ) finanszírozta, a régiók hozzájárulása $(1,3 \mathrm{Mrd} €$ ) sem volt elhanyagolható (Dubois 2018). A nemzeti illetve globális jelentőségű pólusok közti erőteljes hierarchizációt mutatja a támogatások erőteljes koncentrációja: a 6 világszínvonalú pólus (IKT, egészségügy, repülőgépgyártás, nanotechnológiák) osztozott az állami támogatások több mint felén. A jellemzően nagyvárosi térségekben koncentrálódó pólusok térbeli elhelyezkedése nem tette lehetővé a $\mathrm{K}+\mathrm{F}$ térbeli egyenlőtlenségeinek mérséklését: Île-de-France (6), Occitanie (7), PACA (9) Auvergne-Rhône-Alpes (11) régiók a francia pólusok több mint felét koncentrálták, beleértve az állami K+F támogatások fó kedvezményezettjeit jelentő 6 globális pólust is (Grivot 2017). A pólusprogram az „új iparpolitika” eszközeként jól igazolja az állami K+F támogatások multiplikátorhatását: a résztvevő vállalkozások 1 eurónyi állami támogatást 2 euró saját forrással tudtak kiegészíteni. Azonban a növekvő vállalati K+F ráfordítások ellenére elmaradó innovációs output a vállalatok telephelyválasztási döntéseit befolyásoló közpolitikai eszközök gyenge hatékonyságára figyelmeztet (Bellégo et al. 2014; Hassime, Mathieu 2017).

Az államilag indított pólusprogram mellett a 2010-től alapított technológiai transzferintézmények is hatékonyan segítik elő a kollaboratív innovációs projektek létrejöttét. A technológiai transzfer cégek (SATT), technológiai kutatóintézetek (IRT), Carnot-intézetek, ipari technológiai központok (CTI) decentralizált hálózatban müködnek az ország több pontján és fennállásuk óta több tucat stratégiai technológiai projektet, több ezer szabadalmaztatási eljárást és cégalapítást finanszíroztak.

\section{Innovációalapú újraiparosítás}

A francia versenyképességi pólusprogram középső szakaszában kerültek előtérbe a francia Mittelstand-szektor létrehozására vonatkozó kormányzati retorikák, amelyek a „több munkahely, beruházás, kutatás, versenyképesség” által összefoglalható innovációalapú újraiparositási stratégia (Blachier 2017, France Industrie 2019) keretében értelmezhetők. A 2010-ben alakult, főbb iparágak képviselőit tömörítő Nemzeti Ipari Konferencia (CNI) az „Együtt újraiparosithatjuk Franciaországot a növekedés és munkahelyteremtés érdekében" címü jelentésében ismertette a francia ipar növekedésével kapcsolatos legfőbb kihívásokat. A középvállalati szektor gyengeségét az ipari versenyképesség legfőbb akadályai közé soroló Gallois-jelentés (2012) javaslatai visszhangra találtak az Ayrault-kormány által 
kezdeményezett Nemzeti Növekedési, Versenyképességi és Foglalkoztatottsági Paktumban. Ezek többségében versenyképességet javító intézkedések - a középvállalattá válás támogatása, a minőségi termékekre való orientáció elősegítése, a szabályozási és fiskális környezet javítása, a nemzetköziesedés elősegítése és a külföldi befektetők bevonzása. 2013-tól a Nemzeti Ipari Tanács - a 14 ágazati stratégiai tanácson keresztül - jelöli ki a nemzeti iparpolitika prioritásait, együttműködve a 2013-ban alakult France Stratégie nevű kormányzati intézménnyel. Az iparpolitika megerősítésének szándékát tükrözi a France Stratégie francia gazdaság középtávú fejlődésére vonatkozó jelentése (Pisani-Ferry 2014), amely a vállalati szféra gyenge $\mathrm{K}+\mathrm{F}$ aktivitásával összefüggő innovációs versenyhátrány mérséklését, az innovatív vállalkozások németországi arányának elérését definiálja az új iparpolitika céljaként. A francia gazdaság innovációalapú újraiparosítását szorgalmazó gazdasági miniszter szerint a Németországot 15 éven belül lehagyó francia versenyszféra fö problémái a KKV-szektor alacsonyfokú digitalizációjával is összefüggő gyenge innovációs teljesítmény, az innovációk gazdasági diffúziójának hiánya. Noha az ACSEL 2019-es felmérésének eredményei szerint a francia KV-ok magas fokon elkötelezettek a digitális átállás iránt, 60\%-uk számára kiemelt prioritás a termelés digitalizációja, több mint $80 \%$-uk pedig már felállított egy digitalizációért felelős team-et, a digitalizáció előnyeit a francia vállalatok nem tudják kellóképpen kiaknázni. A digitális szektor francia GDP-hez való hozzájárulása - noha meghaladja a repülőgépgyártási vagy gyógyszeripari ágazatét - az OECD adatai szerint csupán 6\%, míg az Egyesült Királyságban vagy Dél-Koreában 10\%, Kínában és az Egyesült Államokban 8-8\%. További problémát jelent, hogy noha Franciaországban a beruházási ráta magasabb, mint Németországban, ez nem jelenik meg sem a versenyképességben, sem a vállalati exportokban. A fenti hiányosságok orvoslását szolgálják a következőkben nagy vonalakban áttekintett 2010 utáni, innováció-alapú újraiparosítási programok, amelyek időközben a versenyképességi pólusokat is integrálták. A kormányzat célja a célzott támogatások révén a delokalizációs trendek megállítása, a gyártás hazatelepítése, az elavult berendezések korszerüsítése, az okos és összekapcsolt gyárakra épülo , jövő iparának” megteremtése, azaz az újraiparosodó Franciaország új arculatának kialakítása, amelynek hordozója a stratégiák fókuszába kerülő középvállalati szektor.

A Jövő beruházásai program a komparatív előnyök jobb kiaknázását célozza olyan stratégiai kulcságazatokba való költséges kormányzati beruházások révén, amelyekre a francia gazdaság a közép-hosszú távú növekedést alapozhatja, és ahol a finanszírozás lehetővé teszi a kritikus méret elérését, pozitív externáliák generálását. Az innováció ipari diffúziója, a kutatási és a felsőoktatási szféra fejlesztése (a finanszírozási források 54\%-a!) mellett a vállalati modernizáció keretében a KKV-k középvállalattá válásának felgyorsítása is a célok között szerepel. Az Ipari Főigazgatóság (SGI) által felügyelt 57 Mrd € költségvetésű program keretén belül az állam a régiókkal közreműködve társfinanszírozza a kiválósági kritériumok alapján kiválasztott vállalati K+F projekteket (biotechnológia, elektronika, 
intelligens hálózatok, szakképzés, informatika területeken). A cél a jövő ipari bajnokainak felkutatása és azok globális piacokon való pozicionálása. A program 2018-2020 közti szakasza (PIA 3, 10 Mrd €) hozzáadódik a nagy beruházási terv (Grand plan d'investissement, GPI) 57 Mrd € költségvetéséhez. A 2018-2022 közt zajló GPI fö területei a karbonsemlegesség ( $20 \mathrm{Mrd} €$ ), a kompetencia alapú társadalom (15 Mrd $€$ ), az innovációalapú versenyképesség (13 Mrd $€$ ) és a digitális állam (9 Mrd €). A „kompetenciák fejlesztését” szolgáló beruházási terv a szakmai képzés reformján keresztül csökkentené a német gazdasághoz képest mért hátrányt, de kiemelt figyelmet fordít a legelesettebbek munkapiaci reintegrációjára is. A kormányzat célja, hogy öt éven belül egymillió alacsonyan képzett munkanélküli, valamint egymillió iskolázatlan fiatal számára biztosítson képzést, a területi szempontokat is figyelembe véve: a fiatal munkanélküliek 14\%-a a várospolitika által kiemelten kezelt „érzékeny városi kerületekből”, 22\%-uk pedig a vidéki revitalizációs övezetekből kerül kiválasztásra. A PIA új fejezetet jelent az iparpolitika koncepcionálásában: a térbeliség szempontjai, a hagyományos iparpolitikai programokra jellemző területfejlesztési, illetve a versenyképességi pólus programra jellemző térbeli agglomerációs logika eltűnésével a hangsúly az innovációs politika, az ágazati prioritások és a kiválóság felé tolódik (Levet 2013; Ravix 2020).

Az 1,3 Mrd € költségvetésü térségi ipari revitalizációs program a hagyományosan ágazati szemléletű iparpolitika területi dimenzióját kívánja erősíteni. Az ipari foglalkoztatottak 50\%-át koncentráló, a nagyvárosi térségektől távol eső, vidéki vagy periurbánus övezetekben elhelyezkedő 124 támogatásra kijelölt „ipari térség" vállalkozói bázisának újradinamizálása azért is kulcsfontosságú feladat, mert egy-egy üzembezárás visszafordíthatatlan hanyatlásba taszíthatja a kis-és közepes városok (gyakran) monoindusztriális gazdaságát.

A francia középvállalati szektor kiszélesítését a francia vállalatok innovációs projektjeit finanszírozó BpiFrance (állami beruházási bank) az ETI2020 középvállalati beruházási alap elkülönített támogatásain, illetve a KKV-akcelerátor programokon keresztül kiemelten támogatja. Az akcelerátor programok révén az állam négy éven belül 4 ezer KKV-t tervez hozzásegíteni a középvállalattá váláshoz. A résztvevő KKV-k minden anyagi és szakmai támogatást megkapnak innovációs és exportpotenciáljaik feltérképezéséhez, növekedési és diverzifikációs stratégiáik megvalósításához, nemzetközi partnerek felkutatásához, a vállalati hálózatokhoz való hozzáféréshez. A francia KKV-k növekedésének legfontosabb eszköze a nemzetköziesedés, ezt a célt szolgálja a 2015-ben létrehozott Business France nevü kormányzati ügynökség. A 2013 óta önálló regionális gazdaságfejlesztési, innovációs és nemzetköziesedési tervek (SRDEII) készítésére kötelezett régiók is együttműködnek az ügynökséggel a területükön működő vállalatok külpiaci tevékenységének támogatásában. A régiók a Business France-szal együttműködve a vállalati szektor digitális átállását is kiemelten támogatják. A regionális tervek vonatkozó célkitüzései szerint 2018-tól minden régióban megvalósul 200 vállalat digitális átállása, miközben az önálló digitalizációs stratégiával rendelkező vállalatok aránya a jelenlegi 20\%-ról 75\%-ra nőhet. 
A KV-bázisra épülő reindusztrializációs stratégiában fontos mérföldkövet jelent a 2019 májusával hatályba lépő PACTE (a francia vállalatok növekedésével és átalakulásával kapcsolatos kormányzati akcióterv). A PACTE kettős célja a vállalatok növekedése előtti jogi és adminisztratív akadályok lebontása, valamint a vállalatok társadalmi megítélésének javítása. A vállalatok keletkezésétől kezdve a cégátadásig terjedő életciklus minden állomását érintő intézkedéscsomag (olcsóbb elektronikus úton történő cégalapítás, a munkaerő tekintetében előírt küszöbértékek, a bértakarékalapok reformja, állami részvények értékesítése és egy állami innovációs alapba történő beforgatása, a külföldi vállalatok ellenőrzése, stratégiai vállalatok védelme, állami kutatások és magánszféra közelítése, a társadalmi és környezeti felelősségvállalás erősítése, stb.) pozitív fogadtatásra lelt a francia KV-ok körében.

A 2013-ban indított Új Ipari Franciaország program (Nouvelle France Industrielle, NFI) a német Ipar 4.0. francia megfelelője (Bourquin 2018), amelynek célja a 4. ipari forradalomban való vezető szerep megszerzése, a dezindusztrializációs veszteségek ellensúlyozása. A vezető szerep megszerzését hátráltatja, hogy Franciaország - a világszínvonalú robotikai alapkutatások ellenére - a gyártás automatizációja terén jelentősen elmarad Németország, Olaszország vagy akár Anglia mögött, a francia vállalatok IKT-beruházásai az eurozóna átlagának felét sem érik el. A KKV-k és az KV-ok korszerüsítését és a digitális átállását támogató 34 „ipari megújulási tervre” épülo program (nanoelektronika, új energiák, zöld vegyipar, cloud computing, e-oktatás, a jövő TGV-je, elektromos repülőgépek gyártása, bioüzemanyagok) 2015-ig 330 ipari beruházást támogatott (3,7 Mrd €). A program jövő ipari ágazataira fókuszáló második fázisában a 34 terv 9 kulcsfontosságú piacra és azok szereplőire lett leszűkítve. A támogatási források menedzsmentje centralizált.

\section{A diszruptív innovációk és a startup vállalkozások}

Franciaország a 2010-es évek eleje óta jelentős forrásokat mobilizál a startupökoszisztéma fejlesztésére, Franciaország innovációs gazdaságból úttörő technológiákon alapuló gazdasággá való átmenetének elősegítésére. A kormányzati politikák legfőbb prioritása, hogy Franciaország a startup befektetések legvonzóbb célpontjává váljon. A francia kormány 2013-ban a közepes (követő jellegü) innovációs teljesítményt nyújtó vállalati szektor diszruptív innovációk felé való orientációjának igényével hozta létre az ipar, a tudomány, a gazdaság és a civil társadalom képviselőiből álló, húsz tagot számláló Innováció 2030 bizottságot. A bizottság feladata a gazdaság hosszú távú fejlődési irányait meghatározó, kisszámú, nagy munkahelyteremtő ágazat és kulcstechnológia beazonosítása, valamint a 2030-ig globális piacvezető pozícióra esélyes, áttörést eredményező innovációt létrehozó vállalatok feltérképezése. A nyolc stratégiai kulcságazat (energiatárolás, fémek újrahasznosítása, tengeri erőforrások hasznosítása, növényi proteinek és növényi biomassza alapú vegyipar, személyre szabott orvoslás, ezüst gazda- 
ság, Big Data, nemzetbiztonság és honvédelem) kijelölését követően a potenciális „nemzeti bajnokok” felkutatása a Concours Mondial innovációs verseny keretében zajlott. ${ }^{9}$

A diszruptív innovációkat középpontba helyező technológiai és innovációs politika központi eleme a mesterséges intelligencia (AI). Franciaország - Dél-Korea, Kína és az Egyesült Államok mellett - 2017 óta rendelkezik nemzeti AI-stratégiával. A francia kormány 2022-ig 1,5 Mrd € közpénzt fordít a stratégiában foglalt célok megvalósítására, kiemelten támogatva a stratégiai kulcságazatokban a potenciális nemzeti bajnokok megjelenését, az AI-vel kapcsolatos strukturális térségi nagyprojekteket. A France Digitale az európai AI-ökosztémát feltérképező elemzése Franciaországot, Németország, az Egyesült Királyság és Spanyolország mellett a négy európai AI-nagyhatalom közé sorolja. E négy ország koncentrálja az európai startupok, kutatólaboratóriumok és közösségek 60\%-át és jelöli ki a főbb irányokat a feltörekvő csillagok valamint a követő országok számára (a négy kulcságazat: tech, pénzügyi szolgáltatások, szórakoztatóipar/média/kultúra és az egészségügy-biotechnológia hasonló arányt képvisel a négy ország esetében).

A francia startup-ökoszisztéma fejlesztése 2014 óta a Mission French Tech nevủ speciális kormányzati irányítású munkacsoport hatáskörébe tartozik. A French Tech kormányzati kezdeményezés célja - szorosan kapcsolódva Franciaország startup-nemzetté alakításának Macron elnök által 2017-ben meghirdetett programjához - a startupokra alapozott térségi ipari revitalizáció és munkahelyteremtés, a startup-ökoszisztémák területi hálózatának, Franciaország digitális nagyhatalmi szerepének megerősítése. A French Tech címet az ökoszisztémák, a startup cégek és az innovatív városok egyaránt elnyerhetik. A French Tech program folytatásaként 2019 őszén a kormány 5 milliárd euró befektetői tőkét ígért a francia startupok számára. A támogatások célja, hogy a francia unikornis cégek száma a többszörösére nőjön (2025-ig a jelenlegi 10-ről 25-re). A startupok léptékváltásának elősegítését szolgálja a French Tech 120, a ,jövő bajnokai”, a hipergyors növekedésủ 120 startup beazonosítására és támogatására létrehozott program. Az új generációs vállalkozások és a diszruptív innovációk finanszírozását szolgálja a 2018-ban létrehozott Ipari Innovációs Alap, amelynek 10 milliárd eurós költségvetését a kormány jórészt állami részvények értékesítéséből finanszírozza. Az alap célja, hogy öt éven belül 1500 startup cégnek nyújtson támogatást és a Franciaországban működő startupok száma a jelenlegi kétszeresére nőjön. A 2019-ben indított deep tech terv keretében az állam éves szinten további 70 millió euró összeggel támogatja a technológiai startup-cégek keletkezését és növekedését. A startupokra irányuló kiemelt kormányzati figyelem több szempontból is indokolt, egyrészt a technológiai startup cégek a 2020-as évtizedben 25 ezer új munkahelyet teremtenek, másrészt erősíthetik Franciaország technológiai szuverenitását.

A diszruptív innovációk előmozdítása terén fontos mérföldkövet jelentett a francia kezdeményezésű terv egy DARPA-szerű, ${ }^{10}$ diszruptív innovációkat ered- 
ményező technológiai projekteket finanszírozó európai ügynökség felállításáról. A diszruptív innovációk állami támogatásának egyesült államokbeli gyakorlatát követi a francia kormány által 2018-ban létrehozott French Tech Seed, a 400 millió euró költségvetésű csúcstechnológiai pénzalap is. A Bpifrance által menedzselt állami kockázati tőkealap a laboratóriumokból, inkubátorokból, technológiai transzferintézményekből kilépő vállalkozásokat támogatja.

A felsorolt intézkedések szerepet játszottak a javuló vállalatalapítási dinamikában: 2017 óta felívelőben van a technológiai startupok száma, ma már több mint 10000 ilyen cég müködik Franciaországban. 2019 első felében a francia startup-cégek első ízben jutottak több tőkéhez (2,2 Mrd €), mint a német startupok (2 Mrd $€$ ). Az Egyesült Királyság fölénye azonban töretlen maradt, ahol ez az érték 5,7 Mrd $€$ volt a jelzett időszakban.

Az intervencionista iparpolitikák irányába történő (előre)lépést jelzi az Alstom-Siemens egyesülés 2019-es vétóját követően a francia és a német gazdasági miniszterek által aláírt kiáltvány („Kiáltvány a 21. század kihívásainak megfelelo” iparpolitikáért"). A kiáltvány az európai versenyszabályok felülvizsgálatát, a gazdasági és technológiai szuverenitás érdekében az európai technológiák fokozottabb védelmét, az állami szerepvállalás újragondolását javasolja, különös tekintettel azokra a kritikus kulcságazatokra (elektromos közlekedés, AI), ahol a két ország szorosabbra fonná az együttműködést. Az iparpolitika szerepét reflektorfénybe helyező francia-német konszenzusos álláspont az európai akkumulátoriparág fellendítésére vonatkozó célkitűzés, kiemelten az elektromos autókhoz gyártott akkumulátorok piacán monopóliumot élvező Airbus-szerű vállalat létrehozása kapcsán kristályosodott ki. Franciaország és Németország az európai autóipar ázsiai akkumulátorgyártóktól való függőségének oldása érdekében indította el 2019 májusában az „akkumulátorgyártás Airbus-a” nevü offenzív protekcionista jellegű ipari kezdeményezését. Az EB 2019 decemberében engedélyezte hét ország (Franciaország, Németország, Olaszország, Lengyelország, Finnország, Belgium, Svédország) számára a konzorciumban résztvevő nagyvállalatok és KKV-k részére történő 3,2 milliárdnyi állami támogatás juttatását. A magánszektor 5 milliárd eurónyi hozzájárulásával együtt a közös európai érdeket képviselő projekt 2031-ig 8 milliárd eurós összegű beruházást jelent, amely az akkumulátor-piacon jelenleg osztozó amerikai, kínai és dél-koreai gyártók irányából érkező versenynyomás miatt többszörösen is indokolt. Az EB az európai ipart és nem a fogyasztókat védő utóbbi döntése precedenst teremthet a versenypolitika iparpolitika feletti primátusának megszüntetésében, olyan esetekben, amikor stratégiai kulcságazatok (ld. a potenciálisan 2-3 millió főt foglalkoztató európai akkumulátor-iparág) és rendkívül magas technológiai és pénzügyi kockázatot jelentő európai érdeket képviselő projektek finanszírozásáról kell döntést hoznia.

Az elmúlt évek vállalkozásbarát és innovációorientált intézkedései azt mutatják, hogy Franciaország sikeres politikát folytat a francia ipar európai és globális pozícióinak visszaszerzése érdekében. Ezt támasztja alá a munkanélküliségi 
ráta csökkenése, a dezindusztrializáció megszűnése (2017 óta az ipar ismét nettó munkahelyteremtő), a német és a francia iparpolitikai álláspontok közeledése. A javuló trendek Franciaország külföldi befektetők általi kedvező megítélésében is tetten érhetők. Az Ernst \& Young (2019) versenyképességi rangsora az európai országok közül Franciaországot az Egyesült Királyság után a második legvonzóbb KMT-célpontnak nyilvánítja, a külföldi ipari befektetések és K+F projektek (144 nemzetközi K+F központ) aránya alapján pedig az európai innovatív beruházások legfőbb célpontjának. Az európai GDP-növekedés lassuló üteme (1,8\%) mellett az EY elemzése kiemeli a francia gazdaság külső konjunkturális és politikai sokkokkal szembeni jó ellenálló képességét. A strukturális befektetések évtizedes elmaradása mindazonáltal komoly gondot jelent Franciaországnak.

\section{Iparpolitikai célokat is támogató regionális gazdaságfejlesztési intézményrendszer}

Fontos cél, hogy az erős regionális középvállalatok minél hatékonyabban járuljanak hozzá a térségi gazdaság teljesítményéhez. Ennek egyik fontos feltétele, hogy a térségi gazdasági szövet minél több lokálisan beágyazódott középvállalkozást tudjon felmutatni. Az állami iparpolitikák kedvezményezettjeiként számon tartott nagy nemzeti bajnok vállalatok telephelyválasztási döntései azonban nem a területi szempontok figyelembevételéről tanúskodnak. A központosító francia modellt nagyjából két évtizeden át háttérbe szorító, ipari decentralizációs politika paradox módon nem a vidéki központok felemelkedését, hanem a tervezési és fejlesztési funkciók fővárosi hiperkoncentrációját erősítette. A vidéki régiók szempontjából előnytelen területi munkamegosztás miatt nem alakulhattak ki a német tartományokhoz (Land) hasonló, versenyképes méretű, a globális gazdasági vérkeringésbe bekapcsolódó, erőteljesen specializált régiók. A centrum-periféria viszonyok továbbélése miatt a francia vállalatok térségi beágyazódása jóval gyengébb, mint Németországban, ahol a térségek és a vállalatok koevolúciója eleve kedvezőbb feltételeket teremtett a területi szempontú politikák megjelenéséhez. A decentralizált müködés hiányzó hagyományai miatt Franciaországban a központi állam kezdeményezésére jelentek meg, elsősorban a delokalizációs tendenciákra adott válaszként a vállalatok térségi beágyazódását, a régiók és a vállalkozások koevolúcióját erősítő országos programok (versenyképességi pólusok, a Jövő Ipari Beruházásai), a számukban csökkenő, méretükben növekvő régiók gazdaságfejlesztési kompetenciáit kiszélesítő decentralizációs reformok, valamint mindazon intézkedések, amelyek a közpolitikák regionalizációjával párhuzamosan a vállalati és innovációs támogatási rendszer kialakítását segítik. A regionális reformok, s mindenekelőtt az állam-régió tervszerződések rendszerének kialakítása óta a (decentralizált és dekoncentrált) regionális szintek egyre nagyobb tervezési és pénzügyi és önállósággal vesznek részt a térségi gazdaságfejlesztésben. 
A kormányzati intézményrendszer mellett ezért az állam alatti szintek, a lokális, regionális intézmények szerepe nagyon fontos, de azért is, mivel a versenyképesség-növelés eszközeinek többsége a gazdaságot körbevevő térségi kerethez kötődik. Az újraiparosítást támogatni képes intézményi hátteret Lux (2017) területi kontextusba ágyazva koherens rendszerként szemlélteti, amely mintegy innovációs folyamatként képes a gazdasági szerkezet átalakítására.

Az állam (és területi szintjeinek) szerepe elsősorban a kedvező üzleti, gazdasági környezet megteremtése, a piaci kudarcok korrekciója és a jól szervezett, elérhető közszolgáltatások biztosítása. A kedvező üzleti környezet egyszerre szolgálhatja a helyi vállalkozások megtartását (fejlesztését) és új vállalkozások vonzását.

A lokális, regionális szintek szereplőinek alapvetően három csoportja említhető. A területi önkormányzatok (illetve önkormányzati együttműködési struktúrák - agglomerációs társulások, települési társulások - köre) elsősorban a gazdaság- és területfejlesztési, területrendezési tervezésben aktívak, illetve együttműködési hálózatok fontos szereplői. A másik csoportba azok a magánvállalkozások sorolhatók, amelyek mindenekelőtt szolgáltatásokkal, finanszírozási konstrukciókkal tudják kiszolgálni a vállalati szektort (hitelintézetek, kockázati tőketársaságok stb.). Franciaországban külön figyelmet érdemel a széles spektrumú tanácsadó cégek, regionális bankok jelenléte és aktivitása. Harmadikként pedig a köztestületi formában működő kereskedelmi és iparkamarákat kell említeni. A kamarai intézményrendszer felépítményéből is, működési struktúrájából eredően is inkább a mikro-, kis- és középvállalkozások számára nyújt érdemi szolgáltatásokat, hiszen tagjai között túlsúlyban vannak ezek a méretű vállalkozások. Ugyanakkor a köztestületi kamarai modell alapvető vonása, hogy a kamarák a helyi, regionális gazdaság egészének érdekeit képviselik, így feladatuk mindig szorosan kapcsolódik a térségi gazdaságfejlesztéshez. A kamarai funkciók közül kiemelendő a partnerségszervezés, az együttmüködési struktúrák ösztönzése és menedzselése, valamint a regionális gazdasági infrastruktúra fejlesztése, működtetése. Az ipar- és innovációs politika sikerének egyik feltétele a szakképzési rendszer hatékony és rugalmas müködése. A szakképzési infrastruktúra müködtetésében is résztvevő kamarák ezért is jelentős regionális szereplők.

\section{Összegzés}

Az állami intézmények leghangsúlyosabb intézkedéseinek célja az innovációs versenyhátrány leküzdése, a duális gazdaság hiányzó láncszemének, az erős regionális középvállalatok számának növelése, valamint a diszruptív innovációk, a startup vállalkozások támogatása. A megújuló francia iparpolitika célja a német ipar teljesítményének utolérése a dinamikus középvállalatok számának növelésével, az innováció sokoldalú támogatásával. Ehhez a Mittelstand-modellt is próbálja adaptálni, amely az ország centralizáltabb berendezkedése miatt kevésbé 
sikeres, de azért is, mert a Mittelstand elsősorban történelmi-kulturális jelenség (nem statisztikai lehatárolás kérdése), s mint ilyen, hosszabb és organikus fejlödést kíván. A német középvállalati szektorhoz való felzárkózást eközben nagymértékben megnehezíti a francia cégek alacsony fokú digitalizációja, a KV-szektoron belül a kisméretű (500 főnél kisebb) cégek dominanciája is. A francia regionális politikában a régiók ipari múltja iránt közömbös, egydimenziós jövőorientált szemlélet nem segítette a regionális gazdaságok sokszínűségét.

Szolgálhat-e tanulságul a hazai iparpolitika, a középvállalkozások fejlődését támogató intézményi környezet számára a francia példa? A válasz nem egyszerü, hiszen mint érzékeltettük is, a francia újraiparosítás sok vita mellett még forrásban van, $\mathrm{s}$ az erjedési folyamat vége egyelőre bizonytalan. Nem látni pontosan, hogy mennyire lesz sikeres az az ETI-ket középpontba állító politika, amely ma a gyakorlatban már inkább csak visszafogottabb formában érzékelhető, s a „startupizáció", amely ma inkább látványos eleme a francia gazdaságpolitikának. Mégis, a kiforratlanság ellenére, és ha mások is a nagyságrendek, a francia középvállalatok kihívásai néhány esetben meglepő egyezést mutatnak a magyarországi közepes cégekével. Egyelőre a francia iparpolitika új eszközeinek hosszú távú hatásai inkább még várakozások, mint eredmények, ám úgy gondoljuk, hogy amennyiben a magyarországi iparpolitika a hazai tulajdonú középvállalati szféra fejlesztését prioritásnak tekinti majd, érdemes a francia példát is áttekinteni.

\section{Jegyzetek}

1 A dezindusztrializáció hatására a foglalkoztatottak 9\%-át (2,13 millió munkavállaló) koncentráló francia autóipar globális pozíciói a 2000-es évek során meggyengültek (2000-ben még a 4. legfőbb exportőr, 2017-ben már csak a 11.).

21970 és 2016 között a feldolgozóipar nemzetgazdasági súlya a felére csökkent (10\%), miközben a kereskedelmi szolgáltatások GDP-hez való hozzájárulása 56,1\%-ra nőtt (Cailletaud 2018). Az ipari ágazat 1970-2018 között 2,5 millió foglalkoztatottat veszített, az ipari hozzáadott érték 13\%-ra csökkent (INSEE 2019).

3 A teljesség igénye nélkül: États Généraux de l'Industrie, Conférence Nationale de l'Industrie.

4 A föderalizált államberendezkedés és a policentrizmus (az 500 ezer fő feletti városok (14) és a 100 ezer fő feletti városok száma (80) többszörösen meghaladja a franciákét), a területi és pénzügyi tőke kiegyenlítettebb eloszlásához vezetett, kedvező feltételeket biztosítva a német KKV-k autonóm fejlődésének, míg a francia centralizmus azt jórészt elfojtotta (Duval 2014).

5 Simon (2012) kutatásában több mint 1300 rejtett bajnokot talált a német KV-szektorban, míg Franciaországban csak 75 ilyen céget sikerült azonosítani.

6 Franciaország az OECD-országok rangsorában a K+F kiadások alapján az 5. helyen, az EU-országok rangsorában a 2. helyen áll. A tudományos publikációk és hivatkozások alapján mért kutatási teljesítmény alapján a globális ranglistákon a 7. helyet foglalja el. 2017-ben az OEB-hez benyújtott szabadalmak arányát tekintve 4. helyen áll a kérelmek 6,5\%-ával (MESRI 2019).

7 2016-ban 15400 vállalat vette igénybe a társasági vagy jövedelmi adójukból levonható, K+F kiadásaik max. 30\%-ig terjedő, összesen 6,1 Mrd € összegnek megfelelő kutatási adójóváírást (CIR), a fiatal innovatív vállalkozás (JEI) státusszal járó munkáltatói társadalombiztosítási járulék alóli mentességet (191 M €) pedig 3202 cég (MESRI 2020). 
8 Egységes Minisztériumközi Alap.

9 A verseny 2014-ben meghirdetett „startup fázisa” során az 1200 pályázó közül a 110 nyertes cég fejenként 200 ezer eurós tőkejuttatásban részesült. A „kockázatcsökkentő” szakaszban a 33 nyertes cég pályázata fejenként 2 millió €, míg 2016-ban a „fejlesztés és iparosítás” fázisban a 7 győztes cég 20-20 millió $€$ támogatást nyert el.

10 Az USA decentralizált iparpolitikai modellje jelentette a fő inspirációt, amely sikeresen tudta ötvözni a diszruptív innovációk és a kiemelten magas kockázatú technológiai projektek állami finanszírozását az angolszász „hands-off” megközelítés retorikájával.

\section{Köszönetnyilvánítás}

A tanulmány elkészítését az NKFIH 115577 sz. szerződése („A hazai középvállalati szektor szerepe az ipar területi versenyképességében") támogatta.

\section{Irodalom}

Beffa, J. L. (2005): Pour une nouvelle politique industrielle. La Documentation Française, Paris

Bellégo, C., Dortet-Bernadet, V. (2014): L'impact de la participation aux pôles de compétitivité sur les PME et les ETI. Économie et Statistique, 471, 65-83. http://doi.org/dmdj

Bignon, N., Simon, M. (2018): Les entreprises en forte croissance. Insee Première, No. 1817.

Blachier, J. L. (2017): Réindustrialiser par l'innovation. Rapport officiel. La Documentation française, Paris

Blanc C. (2004): Pour un écosystème de la croissance. Rapport au Premier ministre, avril 2004

Bleuel, P. (2018): Le Mittelstand et le pragmatisme allemand: un début de solution pour le cas des PME françaises? Revue d'économie industrielle, 2., 9-41. http://doi.org/dmdk

Bost, F., Messaudi, D. (2017): Désindustrialisation, quelles réalités dans le cas français? Revue Géographique de l'Est, Vol.57/1-2.

Bourgeois I. (szerk.) (2010): PME allemandes: Les clés de la performance. CIRAC, Cergy-Pontoise

Bourquin, M. (2018): Faire gagner la France dans la compétition industrielle mondiale. Rapport d'information, Sénat, juin 2018, senat.fr/notice-rapport/2017/r17-551-notice.html

Business France (2018): Tableau de bord de l'entrepreneuriat. www.businessfrance.fr (Letöltés: 2019.11.15.)

Cailletaud, M.-C. (2018): Industrie: un moteur de croissance et d'avenir. Les Avis du CESE, Paris

Ceci-Renaud, N. (2016): Les fonctions de service dans l'industrie manufacturière: La moitié des emplois directs. INSEE Réferences

Cercle de l'Industrie (2017): Propositions du cercle de l'industrie pour 2017-2022 remettre l'industrie au cour de notre projet de société.

Chabaud, D., Messeghem, K. (2014): Les ETI. Un nouvel objet de recherche. Revue Fançaise de Gestion, 7, 95-110. http://doi.org/dmdp

Cohen, E. (2007): Industrial Policies in France: The Old and the New. Journal of Industry, Competition and Trade, Special Issue on The Future of Industrial Policy, 3-4., 213-227. http://doi.org/ft4zg2

Cohen, E., Buigues, P.-A. (2014): Le Décrochage industriel. Fayard, Paris

Colletis, G. (2012): Quelle politique industrielle pour la France? L'Économie politique, 2., 63-78. http:// doi.org/dmdq

CCFA (Comité des Constructeurs Français d'Automobiles) (2019): L'industrie automobile française. Analyse et statistiques. Edition 2018. CCFA, Paris

CNI (2012): Ensemble, réindustrialiser la France pour la croissance et l'emploi. Rapport, Conférence nationale de l'industrie 
Didier, M. (szerk.) (2008): Rapport du groupe de travail sur la définition des catégories d'entreprises, Cnis, Conseil national de l'information statistique

Dahmani S., Gazaniol A., Rioust De Largentaye, T. (2015): Quel avenir pour l'industrie automobile française? Lettre Trésor-Éco, No. 138. Ministère des Finances et des Comptes publics et Ministère de l'Économie de l'Industrie et du Numérique

Demmou, L. (2010): Le recul de l'emploi industriel en France entre 1980 et 2007. Ampleur et principaux déterminants: un état des lieux. Économie et Statistique, 438-440., 273-296. http://doi.org/dmdr

DGCIS (2010): Les entreprises de taille intermédiaire. Les Dossiers de la DGCIS

Dubief, Y. le Pape, J. (szerk.) (2018): La fiscalité de production. Rapport d'IGF, mai 2018

Dubois, D. (2018): Avis sur les crédits „recherche” de la mission interministérielle, „recherche et enseignement supérieur" du projet de loi de finances pour 2019. Avis No. 148, tome V.

Duval, G., Giraud, P-N., Puzo, J., Weil, T. (2014): Les ressorts d'une renaissance industrielle en France. Le journal de l'école de Paris du management, 2., 15-23. http://doi.org/dmdt

Ernst \& Young (2019): Baromètre de l'attractivité de la France 2019.

Fabre, A. (2013): Regards croisés sur l'économie allemande. Bulletin économique du Cirac, 109.

Fontagné, L., Lorenzi, J. H., Artus, P., Fayolle, J., Aubert, P. (2005): Désindustrialisation - Délocalisations. Rapport du CAE. La Documentation française, Paris

Fontagné, L., Mohnen, P. Wolff, G. (2014): Pas d'industrie, pas d'avenir? Notes du conseil d'analyse économique 3 No. 13, 1-12.

France Industrie 2019: Réindustrialiser la France pour pérenniser notre modèle socioéconomique et redynamiser les territoires. k.n., h.n.

Gallois, L., Lubin, C., Thiard, P-E. (2012): Pacte pour la compétitivité de l'industrie française. Rapport au Premier ministre. Documentation française, Paris

Gattaz, Y. (2010): Les ETI, champions cachés de notre économie. Éd. François Bourin, Paris

Giraud, J. (2019): Rapport No. 1990 de la Commission des finances. Économie et commerce extérieure. Annex No. 21. assemblee-nationale.fr. (Letöltés: 2020.01.02.)

Grivot, F. (2017): Quelle politique pour les pôles de compétitivité? Rapport Public. Conseil économique, social et environnemental. Les Avis du CESE, Paris

Groupe BPCE (2016): PME \& ETI, repenser la croissance. BCE l'Observatoire

Guinchard, S. (2014): Ce que nous apprennent les champions cachés. Le journal de l'école de Paris du management, 2., 25-30. http://doi.org/dmdv

Haehnsen, E. (2017): Si la France avait autant d'ETI que l'Allemagne... La Tribune, 25/10/2017. www.latribune.fr/economie/france/si-la-france-avait-autant-d-eti-que-l-allemagne-755407.html (Letöltés: 2018.08.07.)

Hassime H., Mathieu C. (2017): Évaluation de la politique des pôles de compétitivité: la fin d'une malédiction? France Stratégie, Document de Travail, No. 2017-03.

Hénard J. (2012): L'Allemagne: un modèle, mais pour qui?, Presses des Mines, Paris

Industrial Strategy Fund (2012): Mittelstand et performance allemande, que faut-il en retenir? Verbatim record of speeches, 22 November 2012.

INSEE (2019): Les entreprises en France. Édition 2019

Institut Montaigne (2018): ETI: taille intermédiaire, gros potentiel. Rapport 2018

Institut Montagne (2019): Taxes de production: préservons les entreprises dans les territoires. Etude METI et Institut Montaigne

IPP (2019): Budget 2019: Quels effets pour les ménages.

Landier, A. (2013): Désindustrialisation, jusqu'où? L'Usine Nouvelle, 21 novembre 2013.

Les PME dans l'Union européenne génèrent la moitié du commerce intra-UE de biens. Avec un poids légèrement plus élevé dans les importations (2017). Service de presse d'Eurostat. ec.europa.eu/eurostat/documents/2995521/8467304/6-21112017-AP-FR.pdf (Letöltés: 2019.10.12.)

Levet, J., Mathieu, C. (2013): Evaluation ex post du programme d'investissement d'avenir. Rapport du Commissariat général à l'investissement

Levy, J.-D. (2008): From the Dirigiste State to the Social Anaesthesia State. Modern \& Contemporary France, 4., 417-435. http://doi.org/c83hcb

Lux G. (2017): Újraiparosodás Közép-Európában. Dialóg Campus Kiadó, Pécs 
MESRI (2019): L'État de l'Enseignement supérieur, de la Recherche et de l'Innovation en France. No. 12. Ministère de l'Enseignement supérieur de la Recherche et de l'Innovation

MESRI-SIES (2020): Dépenses de recherche et développement en France. Note d'Information du SIES. Ministère de l'Enseignement supérieur, de la Recherche et de l'Innovation

Nesta, L. (2010): Désindustrialisation ou mutation industrielle? Économie et Statistique, 1., 297-301. http://doi.org/dmdw

Pisani-Ferry, J. (2014): Quelle France dans Dix Ans? Les Chantiers de La Décennie. France Stratégie, Rapport au président de la République, Paris

Pisany-Ferry, J. (2016): Quinze ans de politiques d'innovation en France. Rapport de la Commission nationale d'évaluation des politiques d'innovation. France Stratégie, Paris

Ravix, T., Deschamps, M. (2020): Politique de l'innovation et politique industrielle. Serie l'innovation entre le risque et la réussite. ISTE ed., London

Retailleau, B. (2009): Les entreprises de taille intermédiaire au cour d'une nouvelle dynamique de croissance. La Documentation Française, Paris

Roustan, M. (2004): Rapport d'information sur la Désindustrialisation du Territoire. Compte Rendu $N^{\circ} 9$. Délégation à l'aménagement et au Développement Durable du Territoire, Paris

Simon, H., Guinchard, S. (2012): Les Champions Cachés du XXIe Siècle. Economica, Paris

Stoffaës, C. (2008): Mittelstand: notre chaînon manquant. Conseil d'Analyse Economique franco-allemand, Paris

Tavernier J-L. (2019): Tableaux de l'économie française. Édition 2018, INSEE.

Veltz, P. (2013): Paris, France, monde. Editions de l'aube, La Tour-d'Aigues

World Bank (2018): Doing Business 2019: Training for Reform - France. Doing Business 2019. World Bank Group, Washington, D.C.

\section{Internetes források}

www.cercleindustrie.eu

www.assemblee-nationale.fr

www.banquedesterritoires.fr

www.institutmontaigne.org

www.meti.fr

www.lemoci.com

www.insee.fr

www.ifrap.org 